\title{
The Influence of Breastfeeding Initiation on Newborn Body Temperature
}

\section{Desy Syswianti*, Dina Mardiana, and Tri Wahyuni \\ Depatement of Midwifery, Sekolah Tinggi Ilmu Kesehatan Karsa Husada, Garut, Indonesia}

\section{ORCID}

Desy Syswianti: https://orcid.org/0000-0002-6578-2723

\begin{abstract}
Newborns are not yet stable in adequate temperature control, making them vulnerable to heat loss. Early breastfeeding initiation is a factor that affects the temperature of the baby. The mother's skin becomes a thermoregulator or thermal synchrony to warm the baby. The purpose of this research was to determine the influence of early breastfeeding initiation on newborn body temperature. The research was a pre-experimental study with a one-group pretest-posttest design. Participants were newborns born in Midwife Dina Mardiana in July 2019. A digital thermometer was used to measure the baby's temperature. The data analysis technique used was paired sample t tests. The results showed that early breastfeeding initiation had a significant influence on newborn body temperature $(p<0.001)$. The average body temperature increased by $0.46724^{\circ} \mathrm{C}$ after early breastfeeding initiation.
\end{abstract}

Keywords: early breastfeeding initiation, newborn body temperature, newborn

\section{Introduction}

(c) Desy Syswianti et al. This article is distributed under the terms of the Creative Commons Attribution License, which permits unrestricted use and redistribution provided that the original author and source are credited.

Selection and Peer-review under the responsibility of the IVCN Conference Committee.
One of the things that have been a problem in Indonesia's development is the issue relating to maternal and child health. Infant mortality rate (IMR), neonatal mortality rate (NMR), and maternal mortality rate (MMR) are strategic indicators in health development. These issues become the basis of the evaluation for government policies on the health sector and population [1].

The government target that has been set for national medium term development plan (RPJMN) of 2015-2019 is not only to reduce infant mortality rate to 24 per 1000 live births, but also to increase the sustainable development goals (SDGs) in health and welfare sector ( the $3^{\text {rd }}$ SDGs) in 2030, which is to end the infant and toddlers mortality rate. These goals can be achieved by decreasing neonatal mortality rate to 12 per 1000 live births and reducing toddlers' mortality rate to 25 per 1000 live births. For these goals to be achieved, the government needs to work harder [2]. Infant and toddlers' mortality rate and neonatal mortality rate described as follows: 


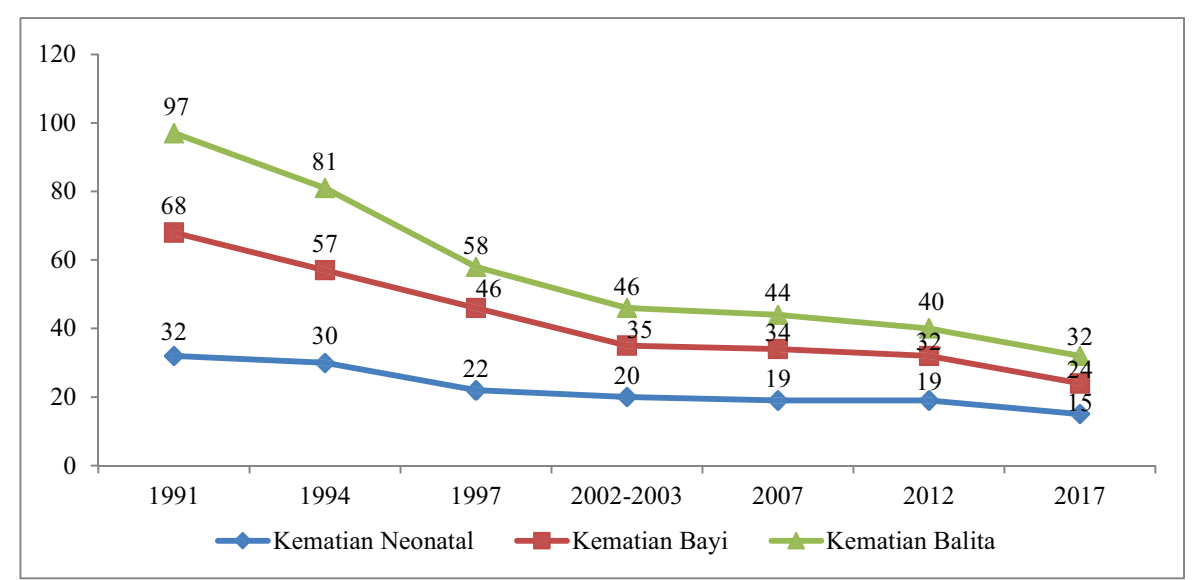

Figure 1: Neonatal mortality rate, infant mortality rate and toddler mortality rate year 1991-2017. source: [2]

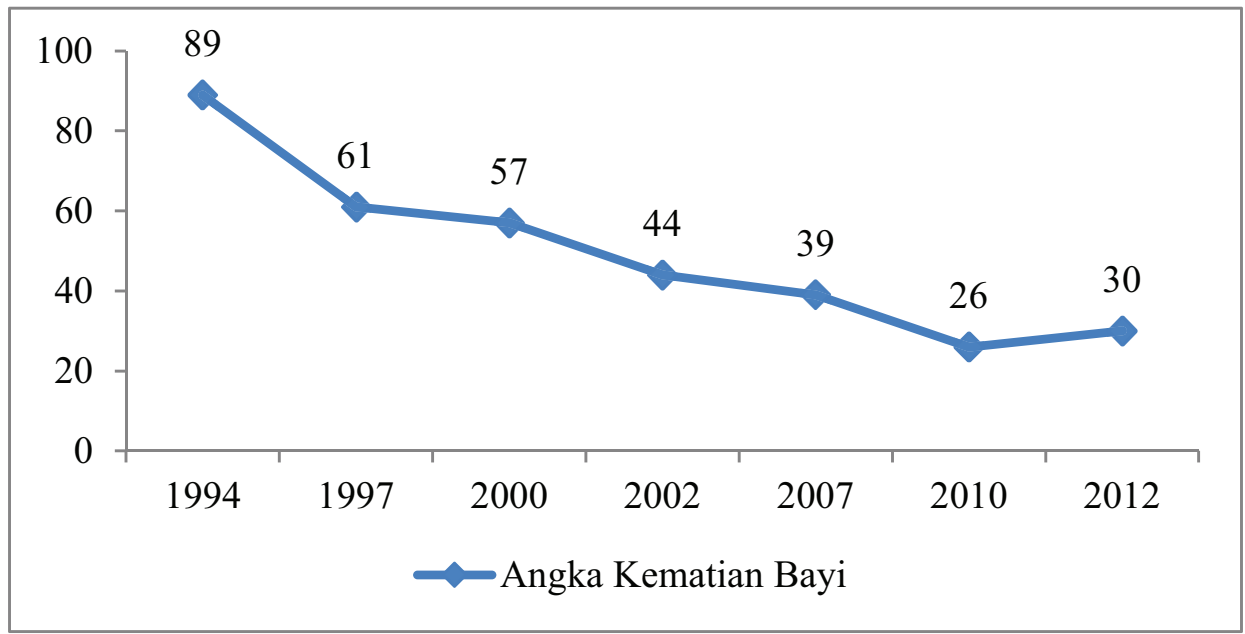

Figure 2: Infant mortality rate on west Java province based on SDKI from year 1994 to 2012

Figure 1 shows us the drop of mortality rate among neonatal, infant and toddlers annually and it is considered as the success of health program conducted by the Indonesian government. Nevertheless, Indonesia is still targeted by the UNICEF's 2018" Every Child Alive" campaign among 10 others country such as Bangladesh, Ethiopia, Guinea-Bissau, India, Malawi, Mali, Nigeria, Pakistan, and the United Republic of Tanzania because Indonesia still be considered to be responsible for half of the world's new born deaths. Through the campaign, UNICEF stakeholders in each country should fulfil their promise to be responsible for universal health coverage (UHC) and saving every child's life [3]

The decreasing number of infant mortality rate also happened in west Java province. It can be seen from the SDKI result as follows:

If we want take a look at the infant mortality rate from its nominal from 2012 to 2107, we can find it on the figure as follows: 


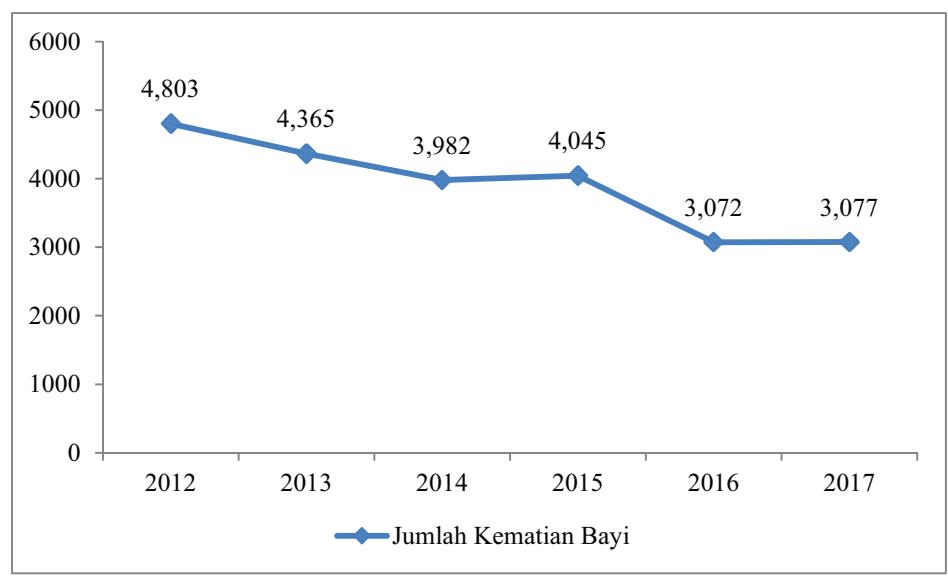

Figure 3: Infant mortality rate on west Java province year 2012 - 2017.

From Figure 2 and 3, we can see that the mortality rate showed a declining trend in 1994- 2012 and also from 2012 - 2017, however, if we take a look the number of infant mortality rate in 2017, it was still quite high and considered to be increasing compared to 2016. This should be a concern for the government of west java province.

Stakeholders of health service in Garut regency should pay attention to the high mortality rate that became a trend since 2013. From 2016 to 2018, Garut regency was the district with the most number of new-borns' deaths in west java province [4]. The highest number of mortality rate occurred in 2016, which were 333 cases higher than 278 cases occurred in 2015 [4].

Several factors can be the causes of the infant mortality rate. Hypothermia is one of the factors that can lead to mortality and morbidity in new-borns. New-borns lose four times more heat than adults do. In the first 30 minutes, baby temperature drops around 3 to 4 degree Celsius. In a room with temperature of 20 to 25 degree Celsius, the baby's skin temperature drops 0, 3 degree Celsius. Babies are prone to hypothermia because they have a wider body surface area than adults do. The cause of hypothermia in infants caused by the environmental exposure such as low temperature, cold or wet surface or the condition when the wet new-borns are without clothes [5].

A low temperature on baby results in slowing metabolic and physiological processes. The breathing speed and heart rate is very slow, the blood pressure is also low, and consciousness will disappear. If this situation is not handled properly, it can cause death in new-borns [6]. The proper prevention is needed so the baby does not experience an extreme temperature lost that leads to hypothermia.

One way to increase the temperature is through early breastfeeding initiation (IMD). Early breast feeding initiation is a process of which letting the baby to find the mother's nipple after birth. The early breast-feeding initiation is carried out by placing the baby 
on the mother's chest and let the baby independently find the nipples for breastfeeding immediately [7]. The mother's breast can be a temperature stabilizer that can regulate a warm the baby so that the baby can avoid the risk of being cold from the adaptation process after postnatal [8].

This research purpose is to find out the new-borns' temperature before and after given the early breastfeeding initiation and to find out the influence of early breastfeeding initiation towards new-borns' temperature.

\section{Method}

This research is an experimental research, which is a research that test a particular treatment to find out that a method, procedure, system, process, tool, material, and model of treatment can be applied or not in a particular object or place [9]. Preexperiment used as its research design, where the research did not use controlled group and the samples were not chosen randomly [10]. The design used on this research was one group pre-test - post-test design.

The population on this research was the entire babies who have born in private practice Midwife Dina Mardiana on July 2019. Saturated sampling used on this research, where the entire population becomes the sample [10]. The inclusion criterion of the research were normal birth, full term (37-42 weeks), and birth weight of 2,500 $-4,000$ grams. The instrument used on this research was digital thermometer to measure the new-borns' temperature. Data collection carried out by measuring the new-borns' temperature before and after early breastfeeding initiation. Samples that are included in the inclusion criteria, after the baby is dried, are measured in newborn body temperature are measured with a digital thermometer before early breastfeeding initiation is performed. After for 1 hour early breastfeeding initiation, the newborn body temperature is measured as a posttest. Correlated sample t test used on this research as data analysis technique.

\subsection{Ethical clearance}

Taken from Health Research Ethics Committee of Sekolah Tinggi Ilmu Kesehatan Karsa Husada, No. 013/KEPK/STIKESKARSAHUSADA/Garut/JABAR/III/2019. 
TABLE 1: Respondents' Characteristics Frequency Distribution

\begin{tabular}{|c|c|c|c|}
\hline No. & Characteristics & f & $\%$ \\
\hline \multirow[t]{2}{*}{1.} & Gender Male Female & 2335 & 39.760 .3 \\
\hline & Total & 58 & 100.0 \\
\hline \multirow[t]{2}{*}{2.} & $\begin{array}{l}\text { Birth Weight } 2500-3000 \text { gram } \\
>3000-3500 \text { gram }>3500- \\
4000 \text { gram }\end{array}$ & 22297 & 37.950 .012 .1 \\
\hline & Total & 58 & 100.0 \\
\hline \multirow[t]{2}{*}{3.} & $\begin{array}{l}\text { Mothers' age }<20 \text { year old } 20 \\
-35 \text { year old }>35 \text { year old }\end{array}$ & 24214 & 3.472 .424 .1 \\
\hline & Total & 58 & 100.0 \\
\hline \multirow[t]{2}{*}{3.} & $\begin{array}{l}\text { The age of mothers' pregnancy } \\
37-39 \text { week }>39-42 \text { week }\end{array}$ & 2236 & 37.962 .1 \\
\hline & Total & 58 & 100.0 \\
\hline
\end{tabular}

TABLE 2: Newborns temperature description

\begin{tabular}{|c|c|c|c|c|}
\hline Variable & Minimum & Maksimum & Average & $\begin{array}{l}\text { deviation } \\
\text { std }\end{array}$ \\
\hline $\begin{array}{l}\text { Newborns temp before IMD } \\
\text { (Pretest) }\end{array}$ & 36.00 & 37.40 & 36.6517 & 0.34297 \\
\hline $\begin{array}{l}\text { Newborns temp after IMD } \\
\text { (Posttest) }\end{array}$ & 36.60 & 37.50 & 37.1190 & 0.24812 \\
\hline
\end{tabular}

\section{Result}

\subsection{Respondents' characteristic descriptions}

The respondents' characteristics in this study include gender, weight, and the age of mother's pregnancy presented in table 1 .

According to the table 1, most of the respondents were females. There were 35 female respondents (60.3\%). there were 29 respondents (50.0\%) whose birth weight were at $>3000$ - 3500 grams, and there were 7 respondents (12.1\%) whose birth weight were at $>3500-4000$ grams. The table 1 also showed that there were 42 respondents (72.4\%) whose age were $20-35$ year old and there were 2 respondents (3.4\%) whose age were $<20$ year old. From the age of pregnancy, we could find out that there were 36 respondents $(62.1 \%)$ whose pregnancy were at $>39-42$ weeks.

\subsection{Newborns temperature description}

New-borns' temperature measured before and after the initiation of early and the result as follows: 
TABLE 3: The frequency distribution of Newborns temperature categories

\begin{tabular}{l|l|l|l|l} 
temperature & \multicolumn{2}{l}{ Newborns temp (Pretest) } & \multicolumn{2}{l}{ Newborns temp (Posttest) } \\
& f & $\%$ & f & $\%$ \\
\hline$<36,5^{\circ} \mathrm{C}$ & 16 & 27.6 & 0 & 0.0 \\
$\geq 36,5^{\circ} \mathrm{C}$ & 42 & 72.4 & 58 & 100.0 \\
\hline Total & 58 & 100,0 & 58 & 100.0
\end{tabular}

Table 2 showed that Table 2 showed that the Newborns temperature was $36.00^{\circ}$ $\mathrm{C}$ to $37.40^{\circ} \mathrm{C}$, with an average of $36.6517^{\circ} \mathrm{C}$ and a standard deviation of $0.34297^{\circ}$ $C$ before initiating Early Breastfeeding (IMD). The Newborns temperature was $36.60^{\circ}$ $\mathrm{C}$ to $37.50^{\circ} \mathrm{C}$, with an average of $37.1190^{\circ} \mathrm{C}$ and a standard deviation of $0.24812^{\circ} \mathrm{C}$ after IMD. We can see that there was an increase of the average value in Newborns temperature by $0.46724^{\circ} \mathrm{C}$ after the IMD treatment.

Table 3 showed that, before being given Early Breastfeeding Initiation (IMD), there were 16 respondents (27.6\%) who experienced hypothermia. As for after being given Early Breastfeeding Initiation (IMD), there were no respondents $(0.0 \%)$ who experienced hypothermia. hypothermia occurred before the IMD, which is a transition of critical period that needs an effort to survive. Newborns need to adapt to a much cooler environment than the temperature in the uterus. The temperature in the uterus is around $37^{\circ} \mathrm{C}$, while the normal room temperature is $25^{\circ} \mathrm{C}-27^{\circ} \mathrm{C}$. Newborns are not yet stable in controlling temperature adequately, making them vulnerable to the heat loss.

Loss of heat in newborns due to evaporation of amniotic fluid on the surface of the baby's body or due to the mechanism of heat loss by means of convection (transfer of heat flow from the body's surface to cooler environments with ambient temperature in cold rooms). A cooler environment and added by the newborn's wet body, will lead to the heat loss of $0.1^{0} \mathrm{C}$ to $0.3^{\circ} \mathrm{C}$ per minute or up to $0.2^{0} \mathrm{C}$ to $1^{0} \mathrm{C}$ per minute if there is no immediate action taken.

\subsection{Hypothesis testing}

Hypothesis testing in this research was conducted using paired sample $t$ test. Paired sample tests are parametric statistics and thus require normal data distribution. In this regard, before testing the hypothesis, the normality of the data was tested first. The results were:

Table 4 showed that the newborns' temperature before and after IMD is normally distributed. This can be seen from the value of $p>0.05$. Based on the distribution of the newborns' temperature data before and after the normal distribution IMD, the 
TABLE 4: Data normality test

\begin{tabular}{l|l|l} 
Variable & $\mathbf{Z}$ \\
$\begin{array}{l}\text { Newborns temp before IMD } 0.099 \\
\text { (Pretest) }\end{array}$ \\
$\begin{array}{l}\text { Newborns temp after IMD } 0.095 \\
\text { (Posttest) }\end{array}$
\end{tabular}

0.200
0.200

Remarks
Normal
Normal

TABLE 5: Paired t test result

the difference of newborns' temp before and after IMD $\mathbf{t}$
\begin{tabular}{l|l} 
average & Std. deviation \\
\hline-0.46724 & 0.23275
\end{tabular}

$-15.289$

p 0.000

requirements for the paired sample t test have been met and we can see the result on table 5 .

Table 5 showed that the average difference in newborns' temperature before and after IMD was -0.46724 and the standard deviation were 0.23275 . A negative average value indicates that the newborns' temperature after being given an IMD has increased. Paired sample t test results obtained a $t$ value of -15.289 and $p$ of 0.000 . Based on $\mathrm{p}<0.05$, it was concluded that Early Breastfeeding Initiation (IMD) had a significant effect on baby's body temperature. The average baby's body temperature increased by $0.467240 \mathrm{C}$ after the Early Breastfeeding Initiation (IMD) conducted. The results of the research did not differ greatly from the results of Wildan \& Febriana's research (2015), which showed the average Newborns temperature of 36.5390 C; and Hutagaol, Darwin, \& Yantri (2014) research result of $36.6^{\circ} \mathrm{C}$ in the experimental group and $36.8^{\circ} \mathrm{C}$ in the control group. Differences on the birth environment, such as room temperature and ventilation produce differences in the average body temperature of newborns.

\section{Discussion}

The results of this study support the results of $[5,7,8,11,12]$. When a newborn initiates Early Breastfeeding (IMD), the mother becomes the heat source for the baby. Mother's skin can be a medium to warm the newborn [13].

The Research Conducted by Dr.Niels Bregman from Africa suggested that the mother's breast skin is 1 degree Celsius hotter than woman who has not delivered the baby. A mother, who just had delivered the baby, could become thermoregulator or thermal synchrony for the baby's temperature. causes the mother to adjust the baby's body temperature. Mother's skin can decrease one degree to cool the baby if the baby is overheated [14]. This is also the reason that after IMD, there were no 
newborns have hypothermia and hypertemia. Mother's skin will maintain the newborns' temperature at normal temperature condition. If we take a look at the results of the research, the Early breastfeeding Initiation (IMD) significantly influences the new-borns' body temperature and if we take a look at the descriptive results, it was found that there were no new-borns who experience hypothermia after IMD. This means that IMD will prevent hypothermia. However, it is necessary to examine temperature changes in the following hours, so that it can be seen how much time it takes the new-borns to adapt their environment, until they reach stability in controlling temperature adequately.

\section{Conclusion}

Based on the results of the research, we can conclude that there were 16 respondents (27.6\%) who experienced hypothermia before being given Early Breastfeeding Initiation (IMD). furthermore, there were no respondents $(0.0 \%)$ who experienced hypothermia after being given IMD. Early Breastfeeding Initiation (IMD) had a significant effect on newborns' temperature. The average newborns' temperature increased by $0.46724^{\circ} \mathrm{C}$ after an Early Breastfeeding Initiation (IMD) was conducted.

\section{Competing interest}

The authors declare that they have no competing interests.

\section{Funding}

No Funding for this research.

\section{References}

[1] National Statistics Agency of Indonesia. Welfare indicators of Jawa Barat Province 2018. 2018.

[2] Windiarto T, Yusuf AH, Santoso AD, et al. Profil anak Indonesia. Jakarta Kementeri Pemberdaya Peremp dan Perlindungan Anak. https://www.kemenpppa.go.id/lib/uploads/list/74d38-buku-pai-2018.pdf

[3] Mahharani A. Red report card for infant mortality rate in Indonesia.

[4] Hidayat J. Garut urges immediately have the motivation to lower AKI / AKB. 
[5] Wardani PK, Comalasari I, Puspita L. Pengaruh inisiasi menyusu dini (IMD) terhadap perubahan suhu tubuh pada bayi baru lahir. Wellness Heal Mag. 2019;1:71-76.

[6] Hutagaol HS, Darwin E, Yantri E. Pengaruh Inisiasi menyusu dini (IMD) terhadap suhu dan kehilangan panas pada bayi baru lahir. Jurnal Kesehatan Andalas. 2014. 3.

[7] Wildan HD, Febriana P. Pengaruh inisiasi menyusu dini terhadap kejadian hipotermia pada bayi baru lahir di puskesmas sumbersari kabupaten jember. Saintika Medika: Jurnal IImu Kesehatan dan Kedokteran Keluarga. 2017;11:34-38.

[8] Chaidir R. Pengaruh inisiasi menyusu dini terhadap suhu tubuh bayi baru lahir di BPM padang panjang. IPTEKS Terapi. 2016;1:20-26.

[9] Usman H, Akbar PS. Metodologi penelitian sosial: Bumi aksara.

[10] Sugiyono DRP. Metode penelitian administrasi dilengkapi dengan metode R\&D.

[11] Ekawati $\mathrm{H}$. The effect of early initiation of breastfeeding (IMD) on changes in body temperature in newborns at the Mitra Husada Maternity Clinic, Pangean Village, Maduran District, Lamongan. J Surya. 2015;7:1-7.

[12] Rahmawati N, Jayanti MSD. Hubungan inisiasi menyusu dini dengan peningkatan suhu tubuh bayi baru lahir di bidan praktek mandiri puji lestari mawung trucuk. INVOLUSI Jurnal IImu Kebidanan. 1.

[13] Setyorini Y, Rustina Y, Nasution Y. Peningkatan suhu bayi baru lahir dan ibu melalui inisiasi menyusu dini. Jurnal Keperawatan Indonesia. 2011;14:45-50.

[14] Rina W, Marianingsih M, Purnamaningrum YA. Pengaruh inisiasi menyusu dini terhadap perubahan suhu bayi baru lahir hari pertama di RSUP Dr soeradji tirtonegoro klaten. Jurnal Teknologi Kesehatan. 2012;8:222-225. 